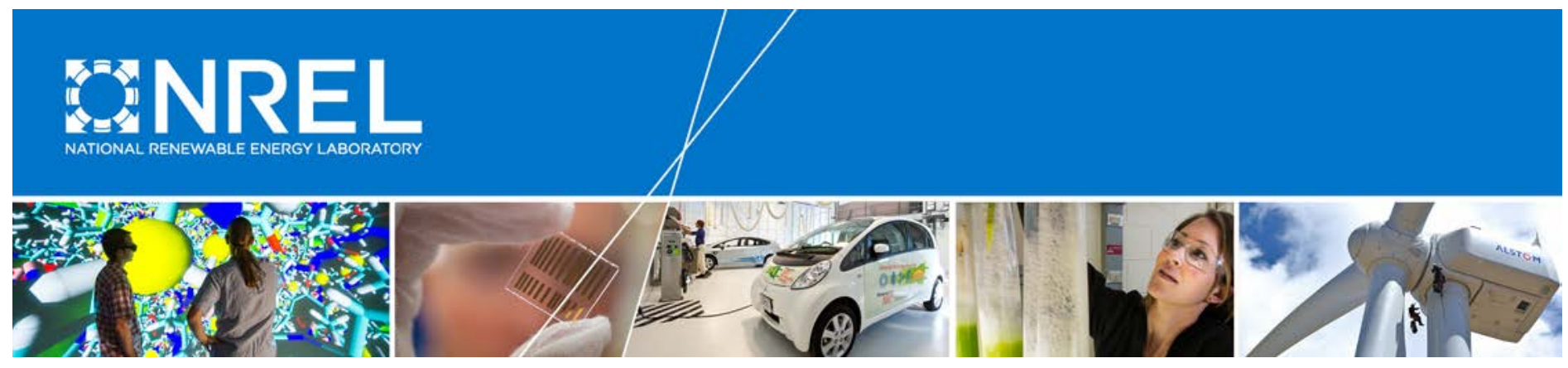

\title{
Gearbox Reliability Collaborative Gearbox 3 Planet Bearing Calibration
}

Jonathan Keller

National Renewable Energy Laboratory

NREL is a national laboratory of the U.S. Department of Energy Office of Energy Efficiency \& Renewable Energy Operated by the Alliance for Sustainable Energy, LLC

This report is available at no cost from the National Renewable Energy Laboratory (NREL) at www.nrel.gov/publications.

Technical Report

NREL/TP-5000-67370

March 2017

Contract No. DE-AC36-08GO28308 


\section{Gearbox Reliability Collaborative Gearbox 3 Planet Bearing Calibration}

Jonathan Keller

National Renewable Energy Laboratory

Prepared under Task No. WE16.5A02
NREL is a national laboratory of the U.S. Department of Energy Office of Energy Efficiency \& Renewable Energy Operated by the Alliance for Sustainable Energy, LLC

This report is available at no cost from the National Renewable Energy Laboratory (NREL) at www.nrel.gov/publications.

\section{Technical Report}

NREL/TP-5000-67370

March 2017

Contract No. DE-AC36-08GO28308
National Renewable Energy Laboratory 15013 Denver West Parkway

Golden, CO 80401

303-275-3000 • www.nrel.gov 


\section{NOTICE}

This report was prepared as an account of work sponsored by an agency of the United States government. Neither the United States government nor any agency thereof, nor any of their employees, makes any warranty, express or implied, or assumes any legal liability or responsibility for the accuracy, completeness, or usefulness of any information, apparatus, product, or process disclosed, or represents that its use would not infringe privately owned rights. Reference herein to any specific commercial product, process, or service by trade name, trademark, manufacturer, or otherwise does not necessarily constitute or imply its endorsement, recommendation, or favoring by the United States government or any agency thereof. The views and opinions of authors expressed herein do not necessarily state or reflect those of the United States government or any agency thereof.

This report is available at no cost from the National Renewable Energy Laboratory (NREL) at www.nrel.gov/publications.

Available electronically at SciTech Connect http:/www.osti.gov/scitech

Available for a processing fee to U.S. Department of Energy and its contractors, in paper, from:

U.S. Department of Energy

Office of Scientific and Technical Information

P.O. Box 62

Oak Ridge, TN 37831-0062

OSTI http://www.osti.gov

Phone: 865.576.8401

Fax: 865.576.5728

Email: reports@osti.gov

Available for sale to the public, in paper, from:

U.S. Department of Commerce

National Technical Information Service

5301 Shawnee Road

Alexandria, VA 22312

NTIS http://www.ntis.gov

Phone: 800.553 .6847 or 703.605 .6000

Fax: 703.605 .6900

Email: orders@ntis.gov 


\section{Acknowledgments}

This work was supported by the U.S. Department of Energy (DOE) under Contract No. DEAC36-08GO28308 with the National Renewable Energy Laboratory. Funding for the work was provided by the DOE Office of Energy Efficiency and Renewable Energy, Wind and Water Power Technologies Office. 


\section{List of Acronyms}

CRB cylindrical roller bearing

GRC Gearbox Reliability Collaborative

$\mathrm{kW} \quad$ kilowatt

$\mathrm{mV} / \mathrm{V} \quad$ millivolts per volt

NREL National Renewable Energy Laboratory

TRB tapered roller bearing 


\section{Table of Contents}

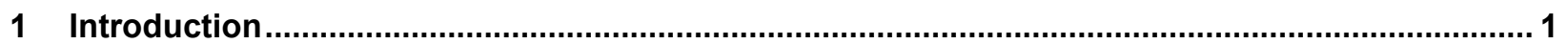

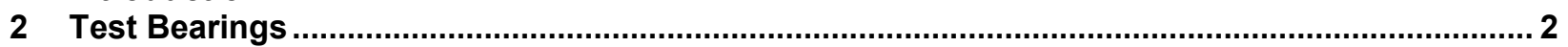

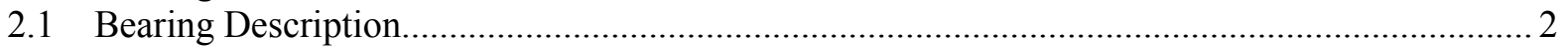

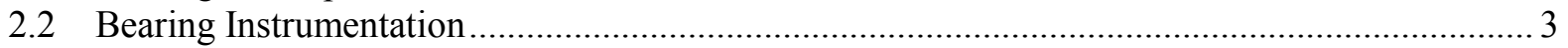

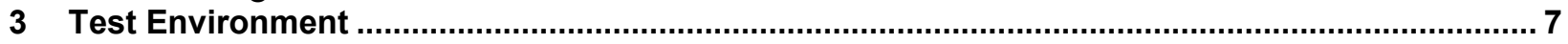

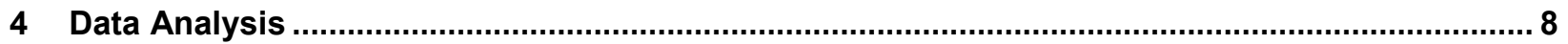

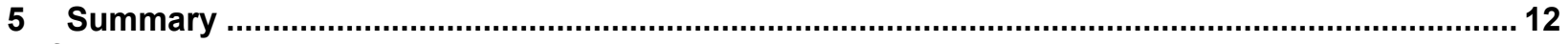

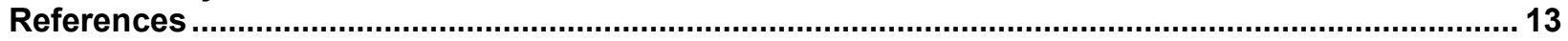

\section{List of Figures}

Figure 1. Gearbox 3 planet bearings. Illustrations by Romax Technology (left) and Timken (right) .......... 2 Figure 2. Planet bearings and gears. Photos by Jonathan Keller, NREL (left) 36523, (middle) 36524, and

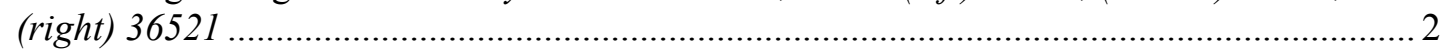

Figure 3. Planet bearing A instrumentation. Illustration by Romax Technology ...................................... 4

Figure 4. Planet bearing B instrumentation. Illustration by Romax Technology ........................................ 5

Figure 5. Planet bearing $\mathrm{C}$ instrumentation. Illustration by Romax Technology ....................................... 6

Figure 6. Planet bearing strain calibration setup. Illustration by Timken ............................................. 7

Figure 7. Regression analysis for Planet A upwind $340^{\circ}$ (left) and downwind $20^{\circ}$ (right) strain gages ...... 8

Figure 8. Regression analysis for Planet B upwind $340^{\circ}$ (left) and downwind $20^{\circ}$ (right) strain gages...... 9

Figure 9. Regression analysis for Planet $\mathrm{C}$ upwind $340^{\circ}$ (left) and downwind $20^{\circ}$ (right) strain gages...... 9

Figure 10. Regression analysis for all Planet $\mathrm{A}$ and $\mathrm{C}$ strain gages...................................................... 11

\section{List of Tables}

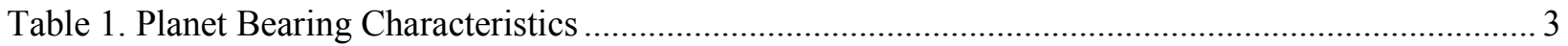

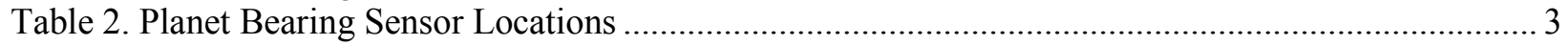

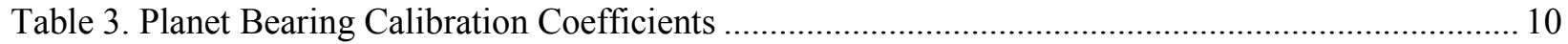




\section{Introduction}

In 2007, the U.S. Department of Energy established the National Renewable Energy Laboratory (NREL) Gearbox Reliability Collaborative (GRC). Its goals are to understand the root causes of premature gearbox failures and to improve gearbox reliability. The GRC uses a combined gearbox testing, modeling, and analysis approach focused on a 750-kilowatt $(\mathrm{kW})$ drivetrain with a nonproprietary, purpose-designed gearbox. Two identical gearboxes, GB1 and GB2, were manufactured and tested to investigate the loads on the cylindrical roller bearings (CRBs) used to support the planets in the gearbox [1]. A major finding was the detrimental effect of rotor nontorque loads (NTLs) on load sharing, predicted fatigue life in high-torque conditions, and the risk of bearing skidding in low-torque conditions [2]. Prior to this testing, the strain gages installed on the planetary bearings were calibrated in a load frame [3]. A similar calibration and bearing loads investigation was also conducted on the tapered roller bearings (TRBs) supporting the high-speed shaft in GB2 [4].

Based on the initial tests of GB1 and GB2, the nonproprietary gearbox design was updated to improve its planetary load-sharing characteristics and predicted fatigue life. This new gearbox is referred to as gearbox 3 (GB3). The most important aspect of the redesign was to replace the CRBs with preloaded TRBs in the planetary section, while the majority of the gearing and housing remained the same [5-8]. Similar to previous work, the strain gages installed on the new planet TRBs were calibrated in a load frame [9]. The new and reused components were assembled and GB3 was recently delivered to the National Wind Technology Center (NWTC). Dynamometer testing is being conducted to measure the actual planet TRB loads [10].

This report describes the calibration tests and provides the factors necessary to convert the measured units from dynamometer testing to bearing loads, suitable for comparison to engineering models. 


\section{Test Bearings}

\subsection{Bearing Description}

The GRC gearboxes discussed in this report are composed of one low-speed planetary stage with three planet gears and two parallel shaft stages. A gearbox internal cut-away and planet TRB schematic are shown in Figure 1. The planet-gear bore was specially designed to serve as the planet bearing outer race. Each planet contains identical but separate upwind and downwind planet bearings. The bore of each planet bearing was also specially designed to include grooves for instrumentation and wire routing, a stop for overload protection, and an anti-rotation keyway $[9,11]$. Both the planet gears and planet bearings, shown in Figure 2, were designed, manufactured, and instrumented by The Timken Company (Timken). Important characteristics of the planet bearings are listed in Table 1 .

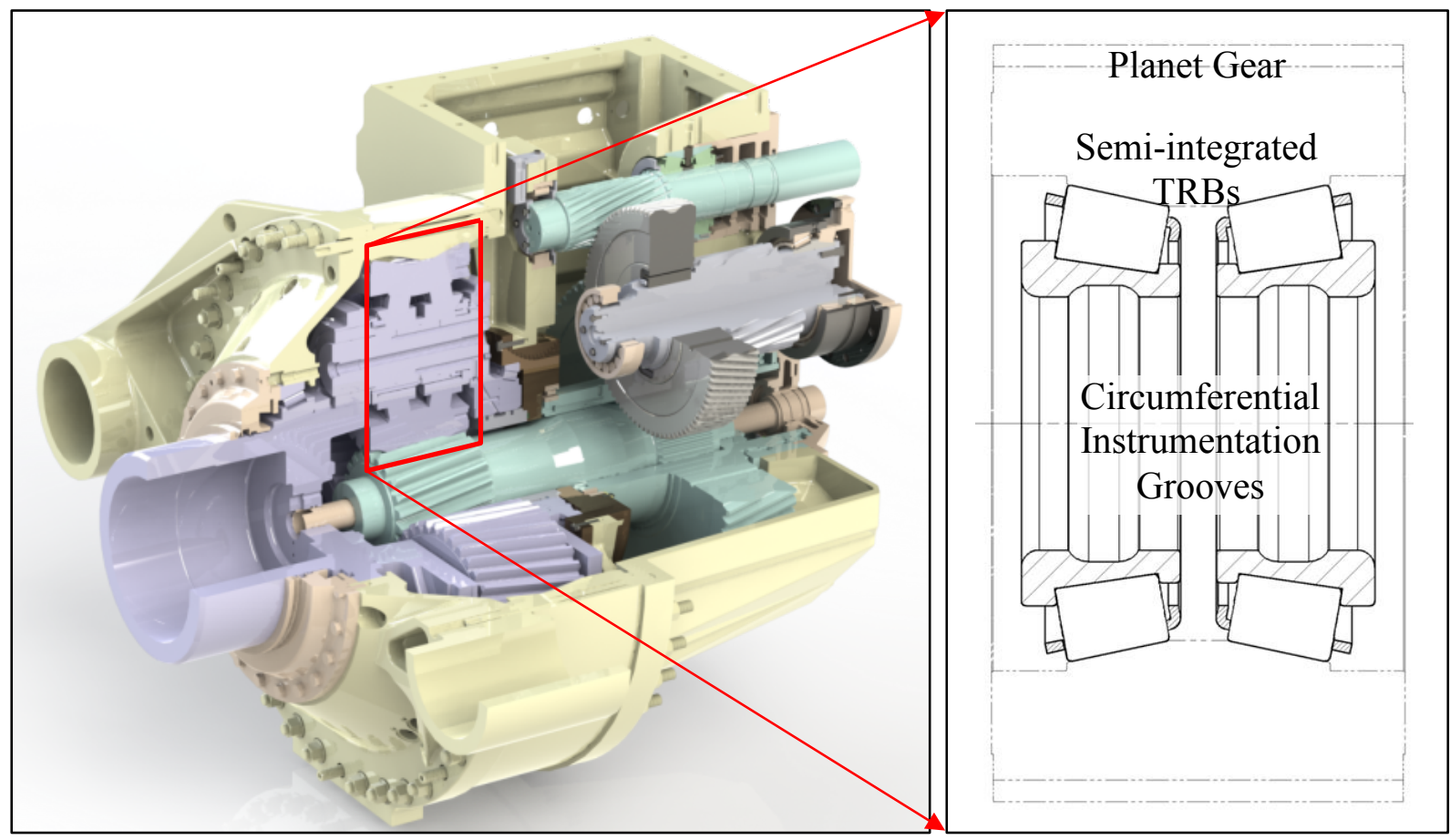

Figure 1. Gearbox 3 planet bearings. Illustrations by Romax Technology (left) and Timken (right)
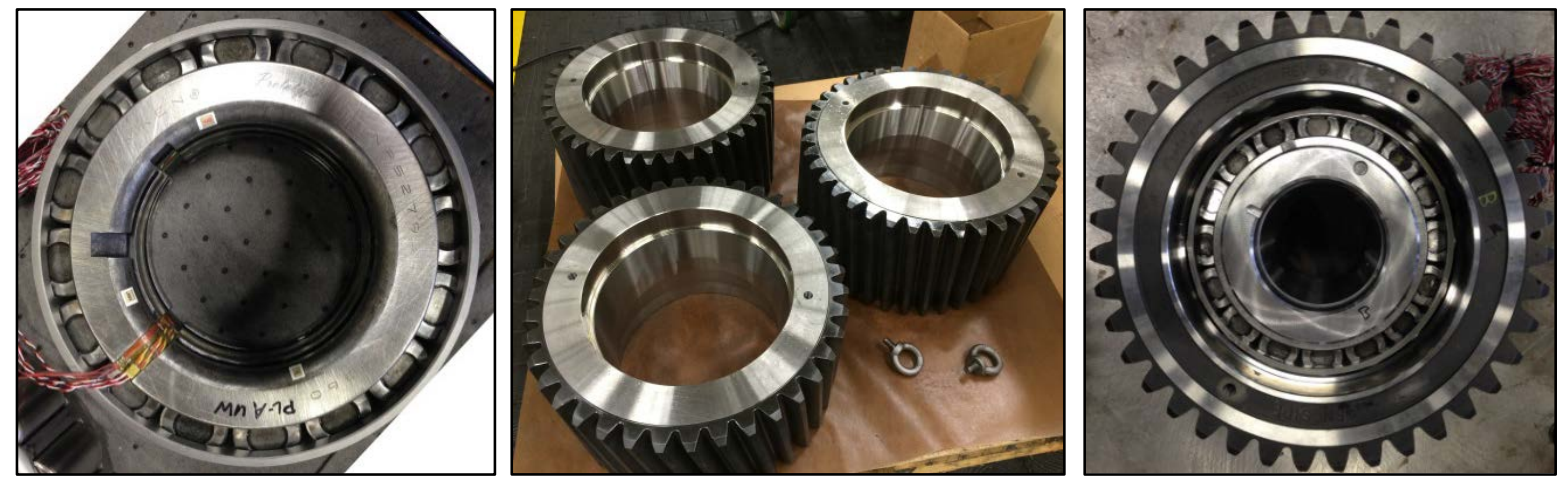

Figure 2. Planet bearings and gears. Photos by Jonathan Keller, NREL (left) 36523, (middle) 36524, and (right) 36521 
Table 1. Planet Bearing Characteristics

\begin{tabular}{ccc}
\hline & Symbol & Value \\
Bearing Designation & & NP527934 \\
Planet Center Diameter & $d$ & $308 \mathrm{~mm}$ \\
Number of Rollers & $Z$ & 16 \\
Poisson's Ratio & $v$ & 0.3 \\
Mounted Contact Angle & $\alpha$ & $10^{\circ}$ \\
\hline
\end{tabular}

\subsection{Bearing Instrumentation}

To assess the planet bearing load distribution and planet-load sharing effectively, one planet bearing pair has more instrumentation than the other two. The planet B bearing set of GB3 has strain measurements at 10 circumferential locations per row to measure the load-zone distribution in detail. The other two planet bearing sets (A and C) have measurements at only four circumferential locations per row [9]. For the complete gearbox, this results in 36 strain measurements. The measurement locations for all three planets are summarized in Table 2 and shown in Figure 3 through Figure 5. The strain gages are Micro-Measurements type EA-06062TT-350, general purpose, $90^{\circ}$ tee rosettes with a gage factor $\left(G_{F}\right)$ of $2.13[12,13]$. The gages are mounted in pairs. The primary gage was aligned with the maximum expected principal strain within the bearing race, whereas the other gage acts as the Poisson gage. Each bearing also contains several thermocouples [10].

Table 2. Planet Bearing Sensor Locations

\begin{tabular}{|c|c|c|}
\hline Planet & Bearing & $\begin{array}{c}\text { GB3 Locations } \\
\text { (clockwise from top dead center) }\end{array}$ \\
\hline \multirow{2}{*}{ A } & $\begin{array}{l}\text { Upwind } \\
\text { (PL-A) }\end{array}$ & 1 axial location at $70^{\circ}, 160^{\circ}, 250^{\circ}$, and $340^{\circ}$ \\
\hline & $\begin{array}{l}\text { Downwind } \\
\text { (PL-B) }\end{array}$ & 1 axial location at $20^{\circ}, 115^{\circ}, 200^{\circ}$, and $285^{\circ}$ \\
\hline \multirow{2}{*}{ B } & $\begin{array}{l}\text { Upwind } \\
\text { (PL-A) }\end{array}$ & $\begin{array}{c}1 \text { axial location at } 10^{\circ}, 32^{\circ}, 70^{\circ}, 160^{\circ}, 250^{\circ} \text {, } \\
288^{\circ}, 310^{\circ}, 327.5^{\circ}, 340^{\circ} \text {, and } 352.5^{\circ}\end{array}$ \\
\hline & $\begin{array}{l}\text { Downwind } \\
\text { (PL-B) }\end{array}$ & $\begin{array}{c}1 \text { axial location at } 7.5^{\circ}, 20^{\circ}, 32.5^{\circ}, 50^{\circ}, 77^{\circ}, \\
115^{\circ}, 200^{\circ}, 285^{\circ}, 323^{\circ} \text {, and } 350^{\circ}\end{array}$ \\
\hline \multirow{2}{*}{ C } & $\begin{array}{l}\text { Upwind } \\
\text { (PL-A) }\end{array}$ & 1 axial location at $70^{\circ}, 160^{\circ}, 250^{\circ}$, and $340^{\circ}$ \\
\hline & $\begin{array}{l}\text { Downwind } \\
\text { (PL-B) }\end{array}$ & 1 axial location at $20^{\circ}, 115^{\circ}, 200^{\circ}$, and $285^{\circ}$ \\
\hline
\end{tabular}




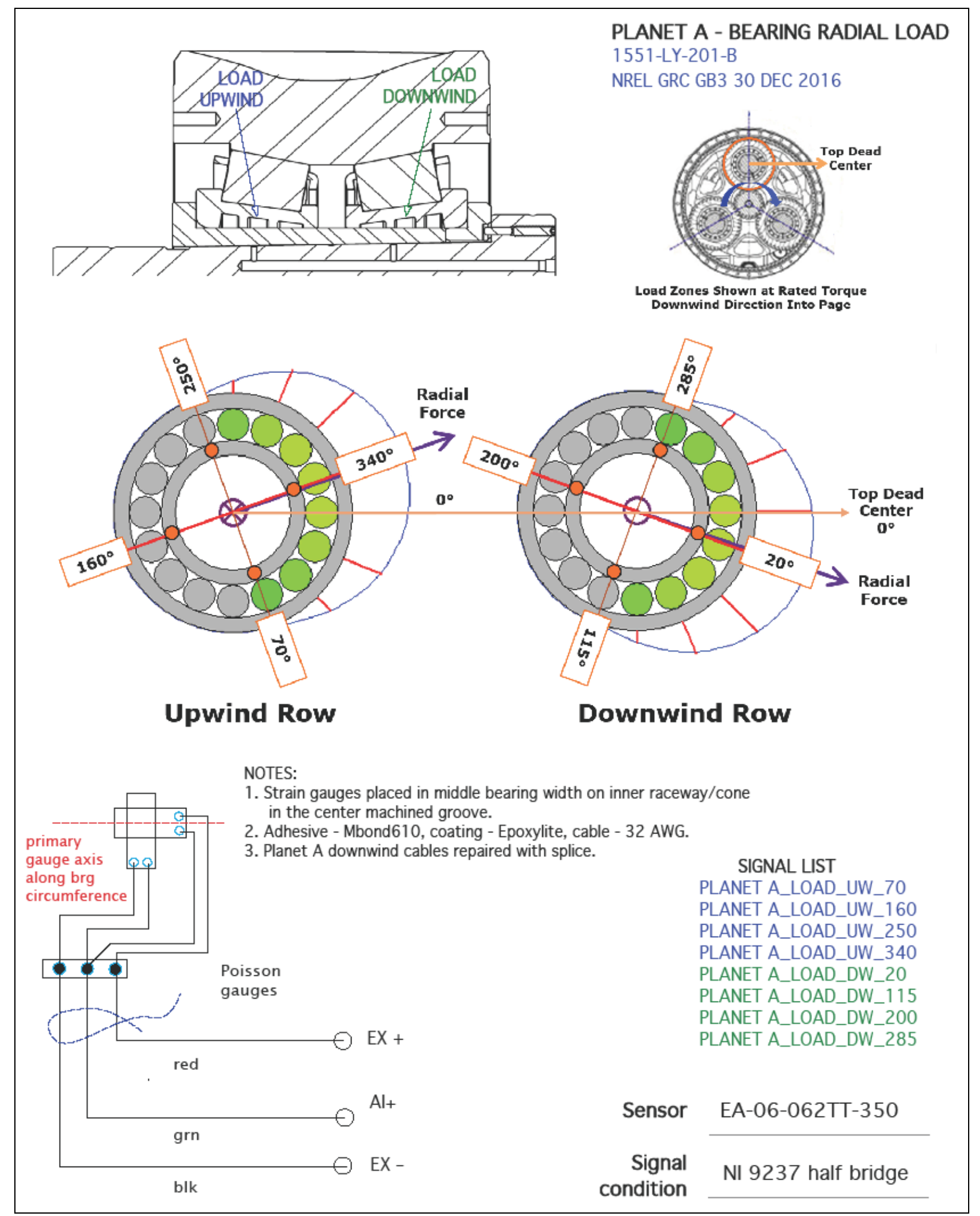

Figure 3. Planet bearing A instrumentation. Illustration by Romax Technology 


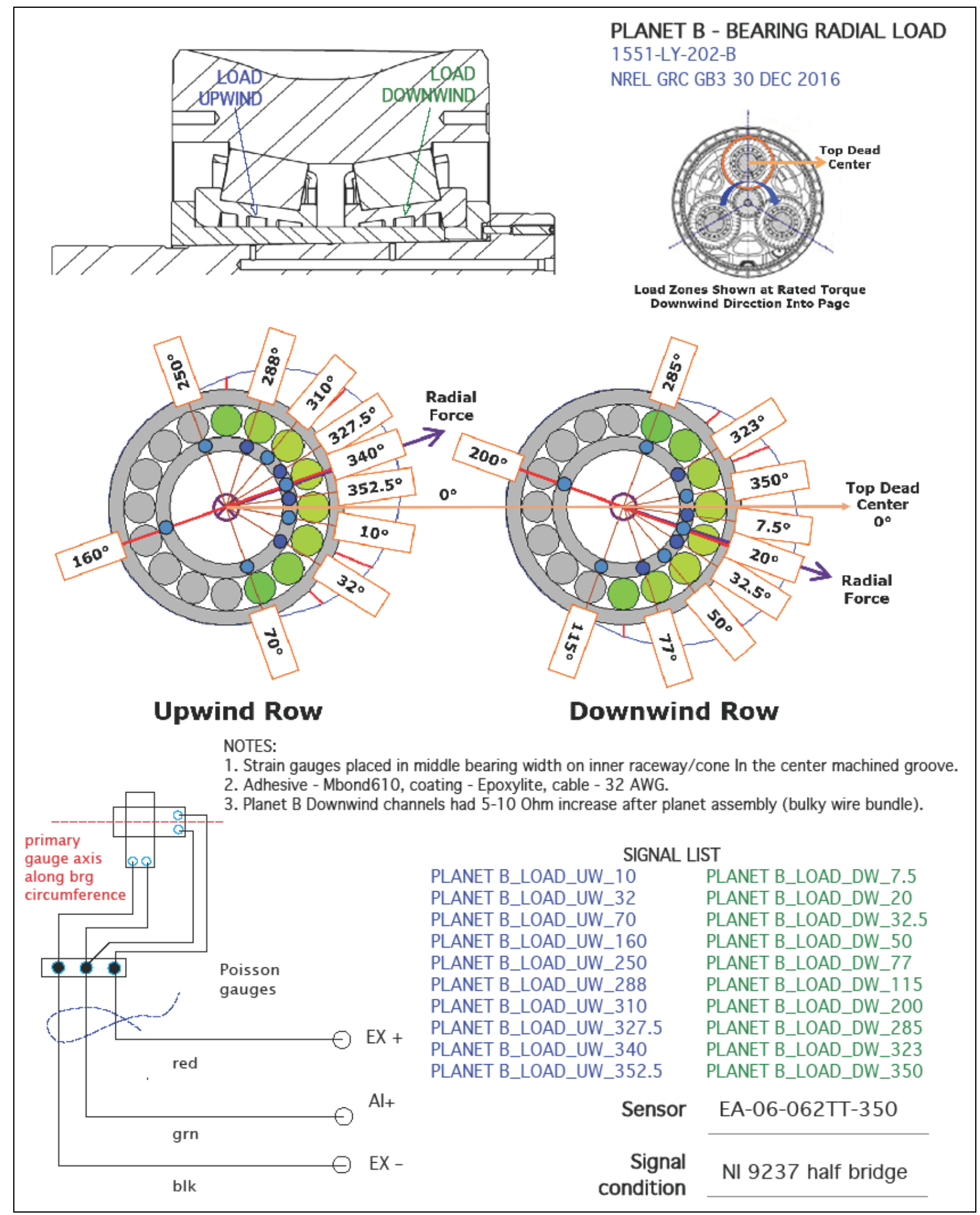

Figure 4. Planet bearing B instrumentation. Illustration by Romax Technology 


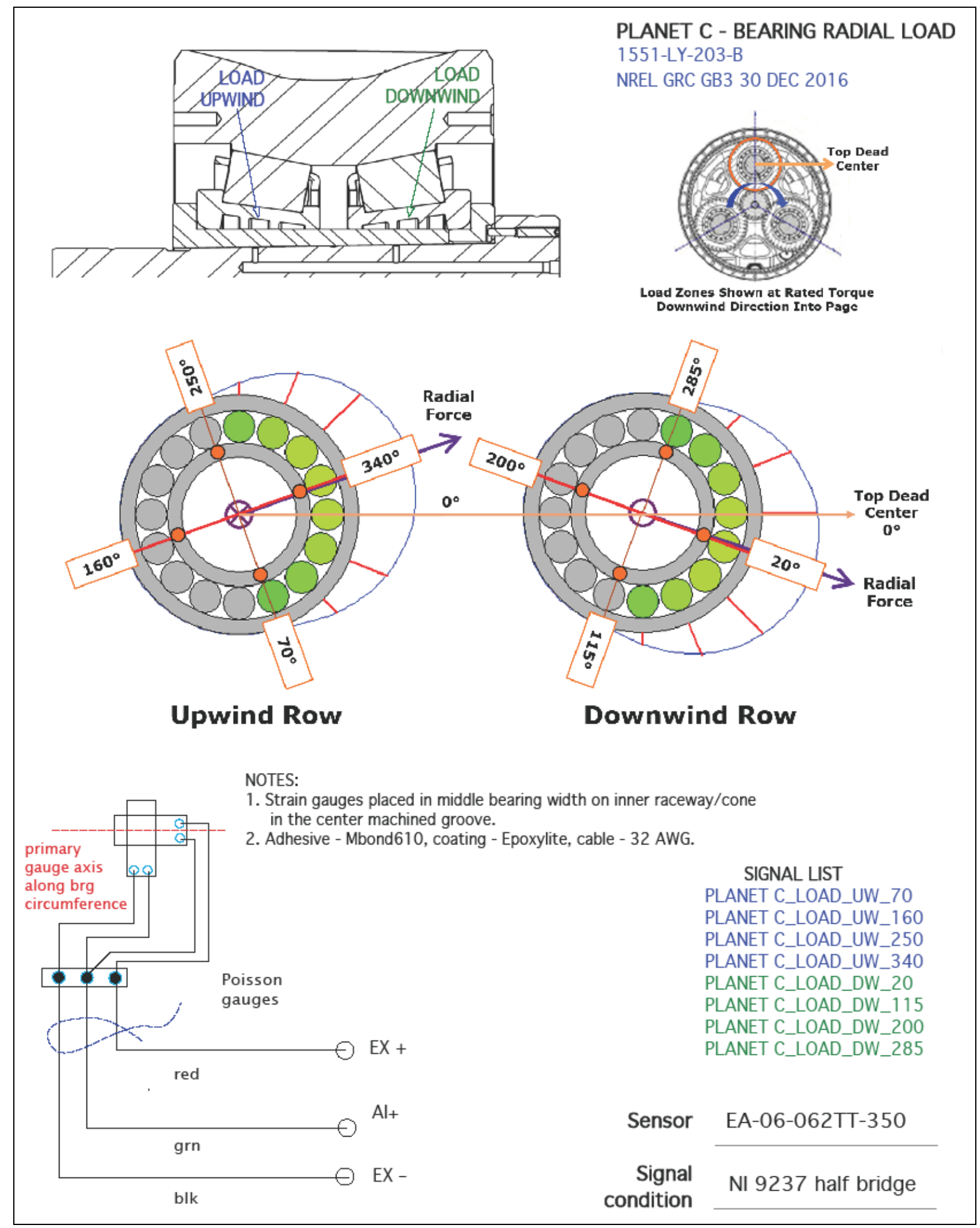

Figure 5. Planet bearing C instrumentation. Illustration by Romax Technology 


\section{Test Environment}

The bearings were calibrated in a load frame at Timken [9], shown in Figure 6. The bearings were not installed with any preload. A press was used to apply a purely axial load $\left(F_{a}\right)$, measured with a calibrated load cell, resulting in roller loads up to $200 \%$ of those expected at rated torque. At each load level, the bearing assemblies were rotated by hand and the resulting strain was measured. Similar to previous testing, the quantity of interest is the difference (maximumminimum, or peak to peak) in strain as the rollers pass over the strain gage pairs, rather than the mean strain $[4,9]$. This difference in strain caused by the roller passage relates the measured strain signal to the bearing load.

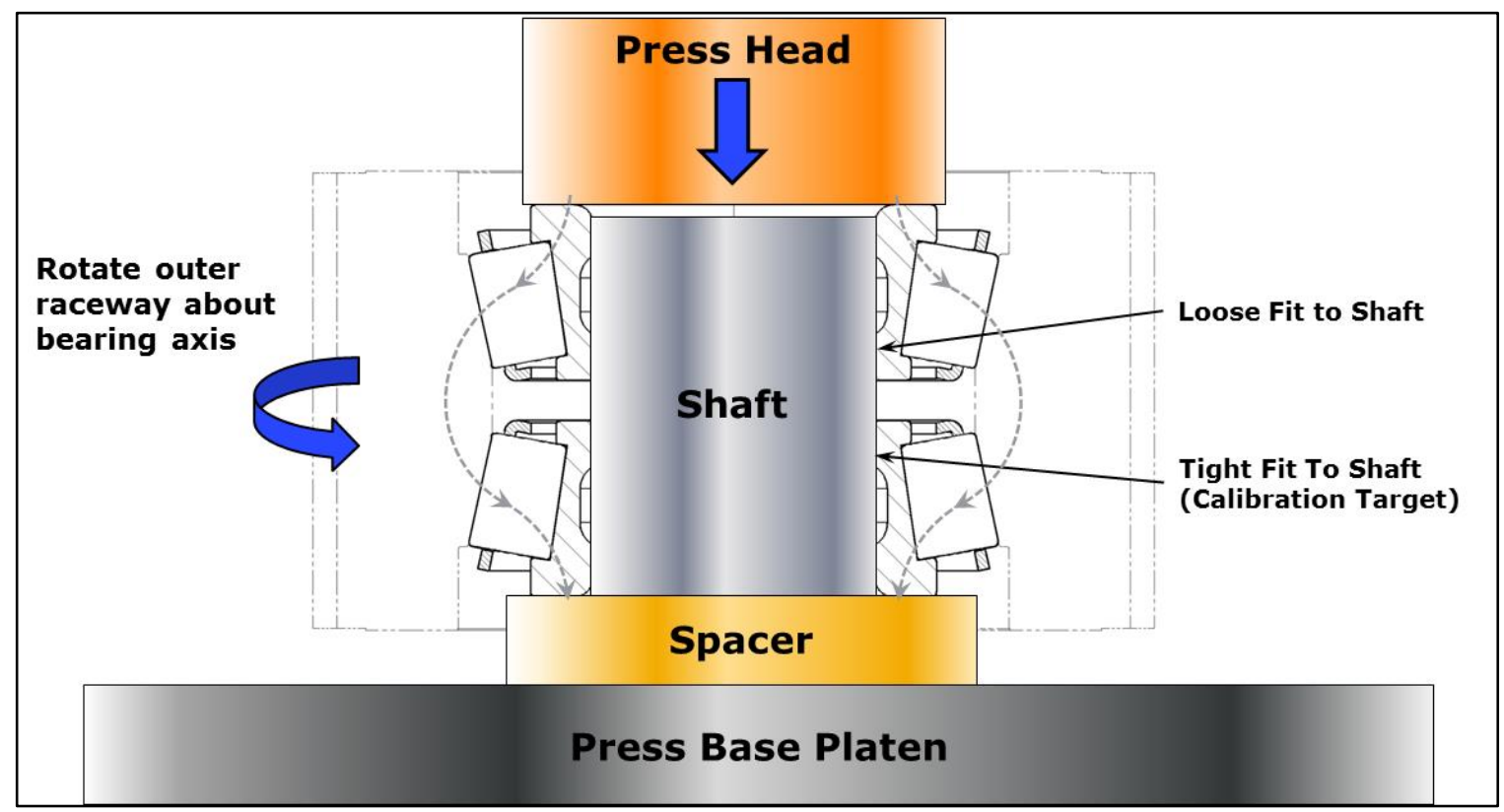

Figure 6. Planet bearing strain calibration setup. Illustration by Timken 


\section{Data Analysis}

Gage calibration is determined from the measured data by regression analysis of each gage response to the applied load. The roller load $(Q)$ normal to the raceway was calculated assuming the applied load was distributed equally among the rolling elements [14].

$$
Q=\frac{F_{a}}{Z \sin \alpha}
$$

The strain is converted from units of millivolts per volt $(\mathrm{mV} / \mathrm{V})$ to millistrain $(\mathrm{m} \varepsilon)$ [15].

$$
m \varepsilon=\frac{4}{G_{F}(1+v)} \frac{m V}{V}
$$

Examples of the regression analysis are shown in Figure 7 through Figure 9 for planets A, B, and $\mathrm{C}$, respectively. In each case, the strain gages at the center of the expected load zone for each bearing are shown. Results for the remaining gages on each planet are similar.
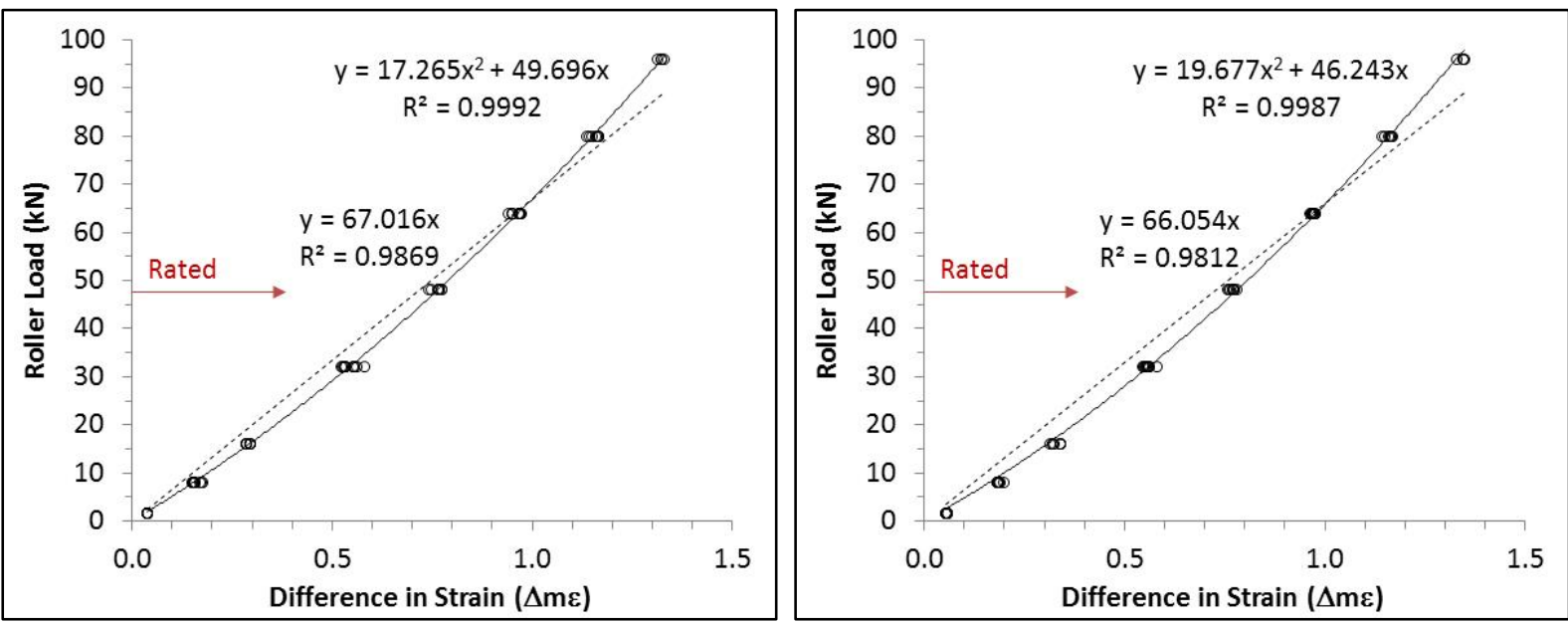

Figure 7. Regression analysis for Planet A upwind $340^{\circ}$ (left) and downwind $20^{\circ}$ (right) strain gages

For the GRC gearboxes, which have three planets and two bearing rows per planet, the maximum expected roller load $\left(Q_{\max }\right)$ at rated torque $(T)$ is approximately [14]:

$$
\begin{aligned}
F_{r} & =\frac{1}{2} \frac{T}{3 d} \\
Q_{\max } & =\frac{4.08 F_{r}}{Z \cos \alpha}
\end{aligned}
$$

It should be noted that Eq. (3) ignores the effect of the overturning moment on the bearing loads because of the helical gearing and mounted preload. For normal operations in the dynamometer, the torque required to produce $750 \mathrm{~kW}$ of electrical power is typically 340 kilonewton-meters, resulting in a maximum roller load of 47.6 kilonewtons $(\mathrm{kN})$, as indicated in each figure. 

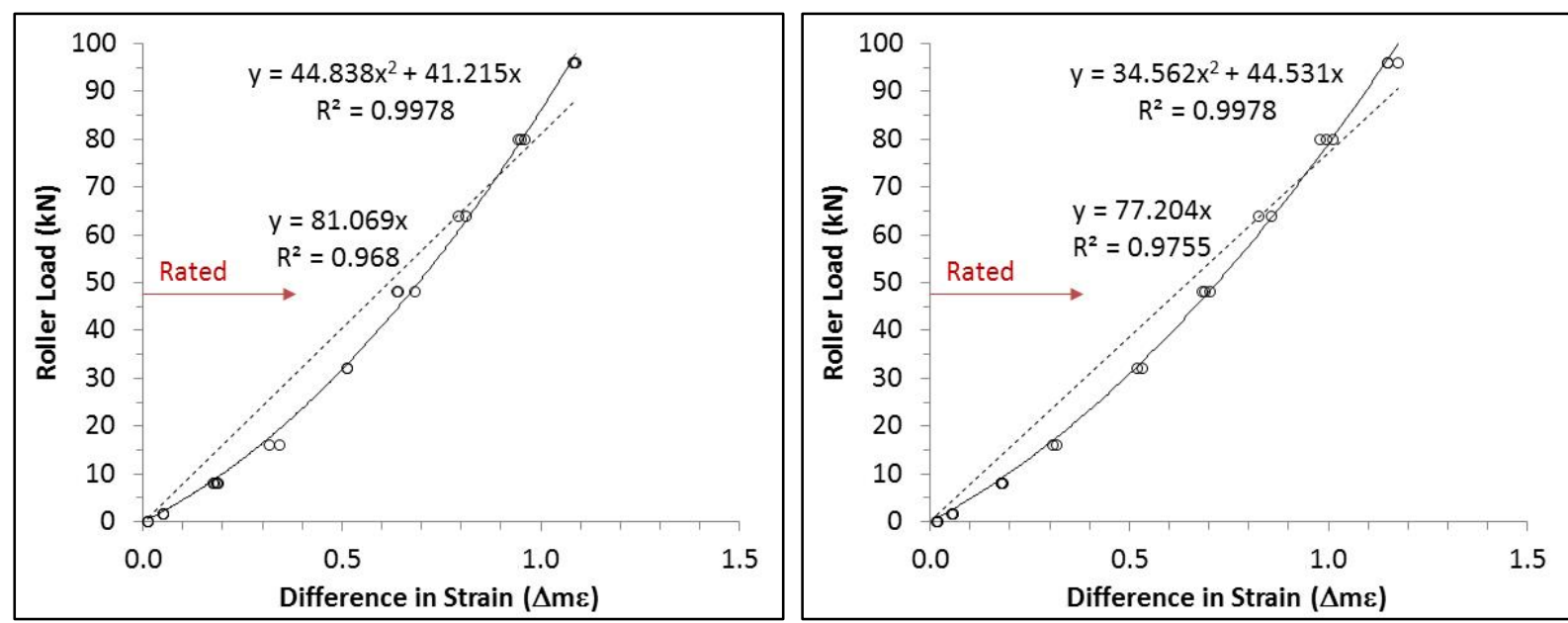

Figure 8. Regression analysis for Planet B upwind $340^{\circ}$ (left) and downwind $20^{\circ}$ (right) strain gages
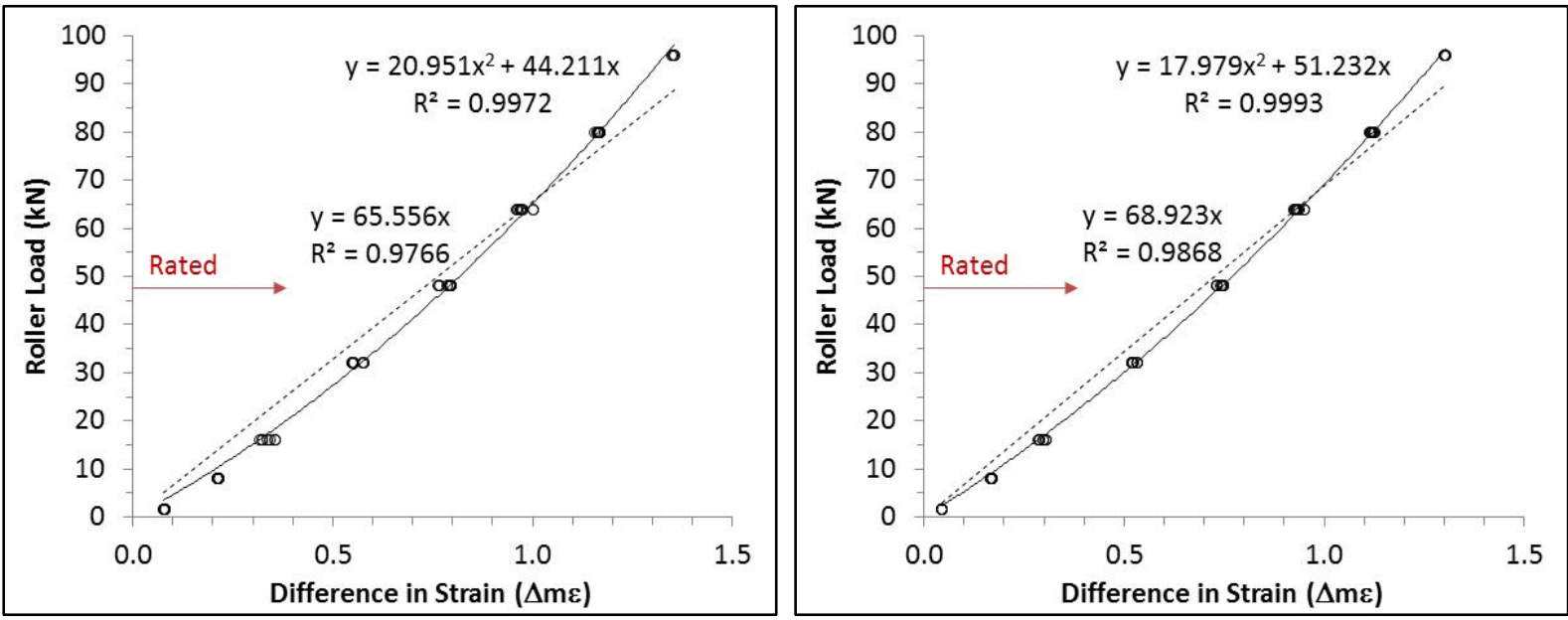

Figure 9. Regression analysis for Planet C upwind $340^{\circ}$ (left) and downwind $20^{\circ}$ (right) strain gages

Although the responses are fairly linear with coefficients of determination $\left(R^{2}\right)$ of over 0.98 , a second order approximation yields an even better fit. The difference between the two fits is most evident at approximately $50 \%$ of rated load. The calibration coefficients for both fits are also shown in the figures. Note that the fits were calculated assuming zero measured strain at zero load. The measured behavior is very similar for the bearings installed in planets $\mathrm{A}$ and $\mathrm{C}$; however, for the bearings installed in planet B the same applied load resulted in approximately $20 \%$ less strain. In operation, the measured roller load for each strain gage measurement can be calculated from

$$
Q=m_{2} \Delta m \varepsilon^{2}+m_{1} \Delta m \varepsilon
$$

where the strain gage measurement is converted from $\mathrm{mV} / \mathrm{V}$ to $\mathrm{m} \varepsilon$ per Eq. (2). The calibration coefficients $\left(m_{2}\right.$ and $\left.m_{1}\right)$ for all 36 strain gage measurements are listed in Table 3 . The calibration coefficients for all gage measurements on planets $\mathrm{A}$ and $\mathrm{C}$ combined are also shown. This combined data set is shown in Figure 10. 
Table 3. Planet Bearing Calibration Coefficients

\begin{tabular}{|c|c|c|c|c|}
\hline Planet & Bearing & $\begin{array}{c}\text { Circumferential } \\
\text { Location }\end{array}$ & $\underset{\mathrm{kN} /(\Delta \mathrm{m} \varepsilon)^{2}}{\mathbf{m}_{\mathbf{2}}}$ & $\begin{array}{c}\mathbf{m}_{1} \\
\mathrm{kN} / \Delta \mathrm{m} \varepsilon\end{array}$ \\
\hline \multirow{7}{*}{ A } & \multirow{5}{*}{$\begin{array}{l}\text { Upwind } \\
\text { (PL-A) }\end{array}$} & $70^{\circ}$ & 16.713 & 48.949 \\
\hline & & $160^{\circ}$ & 17.718 & 45.749 \\
\hline & & $250^{\circ}$ & 19.620 & 48.406 \\
\hline & & $340^{\circ}$ & 17.265 & 49.696 \\
\hline & & $20^{\circ}$ & 19.677 & 46.243 \\
\hline & \multirow{3}{*}{$\begin{array}{l}\text { Downwind } \\
(P L-B)\end{array}$} & $115^{\circ}$ & 20.987 & 47.710 \\
\hline & & $200^{\circ}$ & 18.965 & 53.086 \\
\hline \multirow{21}{*}{ B } & & $285^{\circ}$ & 20.239 & 45.078 \\
\hline & \multirow{11}{*}{$\begin{array}{l}\text { Upwind } \\
\text { (PL-A) }\end{array}$} & $10^{\circ}$ & 34.396 & 46.456 \\
\hline & & $32^{\circ}$ & 31.828 & 51.679 \\
\hline & & $70^{\circ}$ & 29.820 & 59.543 \\
\hline & & $160^{\circ}$ & 35.862 & 44.961 \\
\hline & & $250^{\circ}$ & 32.104 & 55.253 \\
\hline & & $288^{\circ}$ & 34.004 & 53.745 \\
\hline & & $310^{\circ}$ & 44.779 & 47.100 \\
\hline & & $327.5^{\circ}$ & 43.970 & 45.736 \\
\hline & & $340^{\circ}$ & 44.838 & 41.215 \\
\hline & & $352.5^{\circ}$ & 45.915 & 44.105 \\
\hline & & $7.5^{\circ}$ & 35.108 & 45.009 \\
\hline & \multirow{9}{*}{$\begin{array}{l}\text { Downwind } \\
\text { (PL-B) }\end{array}$} & $20^{\circ}$ & 34.562 & 44.531 \\
\hline & & $32.5^{\circ}$ & 35.668 & 47.145 \\
\hline & & $50^{\circ}$ & 32.267 & 52.359 \\
\hline & & $77^{\circ}$ & 35.854 & 49.138 \\
\hline & & $115^{\circ}$ & 37.392 & 49.492 \\
\hline & & $200^{\circ}$ & 38.541 & 39.988 \\
\hline & & $285^{\circ}$ & 34.673 & 43.792 \\
\hline & & $323^{\circ}$ & 37.185 & 42.092 \\
\hline & & $350^{\circ}$ & 34.854 & 46.819 \\
\hline \multirow{8}{*}{ C } & \multirow{5}{*}{$\begin{array}{l}\text { Upwind } \\
\text { (PL-A) }\end{array}$} & $70^{\circ}$ & 17.245 & 48.062 \\
\hline & & $160^{\circ}$ & 17.968 & 48.375 \\
\hline & & $250^{\circ}$ & 17.890 & 53.978 \\
\hline & & $340^{\circ}$ & 20.951 & 44.211 \\
\hline & & $20^{\circ}$ & 17.979 & 51.232 \\
\hline & \multirow{3}{*}{$\begin{array}{l}\text { Downwind } \\
(P L-B)\end{array}$} & $115^{\circ}$ & 20.648 & 51.337 \\
\hline & & $200^{\circ}$ & 21.108 & 47.512 \\
\hline & & $285^{\circ}$ & 17.296 & 53.484 \\
\hline$A$ and $C$ & Both & All & 17.826 & 49.846 \\
\hline
\end{tabular}




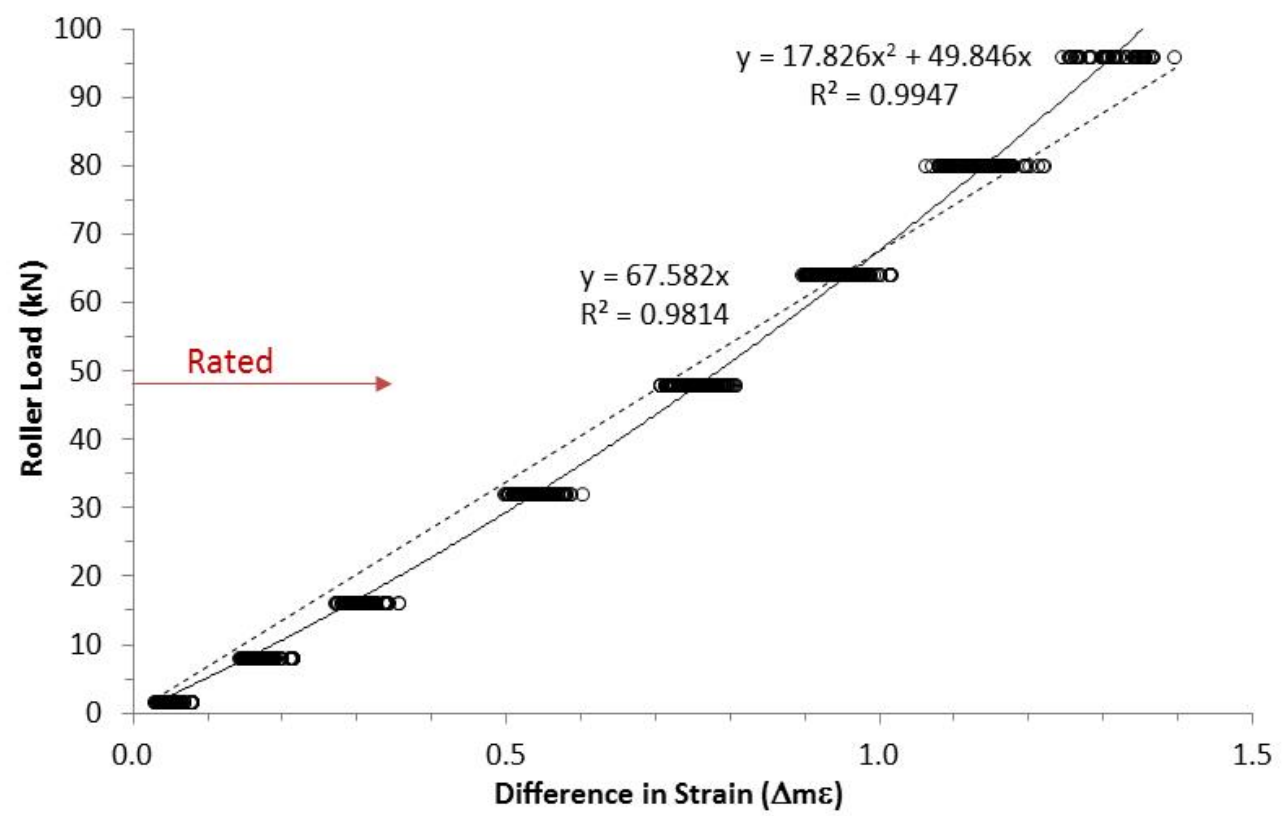

Figure 10. Regression analysis for all Planet $A$ and $C$ strain gages 


\section{Summary}

An instrumentation package was designed, installed, and calibrated for the tapered roller bearing pairs supporting the GRC GB3 planets. The instrumentation consisted of 36 strain gage pairs installed in circumferential grooves machined in the inner ring of each bearing. The gages were wired in a Poisson half-bridge configuration and measured the strain response when a roller passed underneath the gage pairs.

The strain gages underwent calibration testing in June 2014 in a load frame located at Timken. The load frame applied axial loads resulting in roller loads up to $200 \%$ of those expected at rated torque. At each load condition, the bearings were rotated and the resulting strain response was recorded. The strain gage response during the bearing rotation was then postprocessed to extract the strain range. A regression analysis was used to correlate each of the 36 measured half-bridge outputs with the roller load, resulting in calibration factors suitable for analysis of data gathered during planned dynamometer testing of the gearbox and comparison to engineering models. Validation of the engineering models with test data will demonstrate the improvements in load sharing and the theoretical increase in planetary section fatigue life. 


\section{References}

1. H. Link, W. LaCava, J. van Dam, B. McNiff, B.S. Sheng, R. Wallen, M. McDade, S.

Lambert, S. Butterfield, F. Oyague. 2011. Gearbox Reliability Collaborative Project Report:

Findings from Phase 1 and Phase 2 Testing (Technical Report). NREL/TP-5000-51885.

National Renewable Energy Laboratory (NREL), Golden, CO

(US). http://www.nrel.gov/docs/fy11osti/51885.pdf.

2. Y. Guo, J. Keller, and W. LaCava. "Planetary gear load sharing of wind turbine drivetrains subjected to non-torque loads," Wind Energy, 18 (2014): 757-768. doi.10.1002/we.1731.

3. J. van Dam. 2011. Gearbox Reliability Collaborative Bearing Calibration (Technical Report). NREL/TP-5000-47852. National Renewable Energy Laboratory (NREL), Golden, CO (US). http://www.nrel.gov/docs/fy12osti/47852.pdf.

4. J. Keller, Y. Guo, and B. McNiff. 2013. Gearbox Reliability Collaborative High Speed Shaft Tapered Roller Bearing Calibration (Technical Report). NREL/TP-5000-60319. National Renewable Energy Laboratory (NREL). Golden, CO (US). http://www.nrel.gov/docs/fy14osti/60319.pdf.

5. J. Keller, M. McDade, W. LaCava, Y. Guo, and S. Sheng. "Gearbox Reliability Collaborative Update," NREL/PR-5000-54558. National Renewable Energy Laboratory (NREL). Golden, CO (US). Presented at the Wind Energy Operations \& Maintenance Summit USA, Dallas, Texas, April 26, 2012. http://www.nrel.gov/docs/fy12osti/54558.pdf.

6. S. Sheng, J. Keller, and C. Glinsky. "Gearbox Reliability Collaborative Update," NREL/PR5000-60141. National Renewable Energy Laboratory (NREL). Golden, CO (US). Presented at the Sandia Reliability Workshop, Albuquerque, New Mexico, August 13-14, 2013. http://www.nrel.gov/docs/fy14osti/60141.pdf.

7. J. Keller. "Wind Turbine Drivetrain Testing and Research at the National Renewable Energy Laboratory," NREL/PR-5000-62887. National Renewable Energy Laboratory (NREL). Golden, CO (US). Presented at Pennsylvania State University, University Park, Pennsylvania, September 15, 2014. http://www.nrel.gov/docs/fy15osti/62887.pdf.

8. J. Keller. "Gearbox Reliability Collaborative: Gearbox 3 Manufacturing Status," NREL/PR5000-63869. National Renewable Energy Laboratory (NREL). Golden, CO (US). Presented at the Gearbox Reliability Collaborative Meeting, Boulder, Colorado, February 17-18, 2015.http://www.nrel.gov/docs/fy15osti/63869.pdf.

9. Marks, C. 2013. NREL GRC Gearbox \#3 Integrated TRB Planet Bearings. Gearbox Reliability Collaborative Meeting, Golden, CO.

10. J. Keller and R. Wallen. 2016. Gearbox Reliability Collaborative Phase 3 Gearbox 3 Test Plan (Technical Report). NREL/TP-5000-66594. National Renewable Energy Laboratory (NREL), Golden, CO (US). http://www.nrel.gov/docs/fy17osti/66594.pdf.

11. M. Wilmer, C. Marks, and T. Barr. Load sensing bearing assembly, PCT/US2014/023227. 
12. Micro-Measurements, General Purpose Strain Gages-Tee Rosette. August 2016. http://www.vishaypg.com/docs/11100/062tt.pdf.

13. J. Graeter. 2016. Verification Report: Installed Instrumentation Equipment at NREL NWTC, Romax Technology Report 1551-DC-004-A.

14. T. Harris and M. Kotzalas, Essential Concepts of Bearing Technology. Fifth Edition. Taylor \& Francis.

15. Micro-Measurements, Errors Due to Wheatstone Bridge Nonlinearity, Tech Note TN-507-1, November 2010. http://www.vishaypg.com/docs/11057/tn5071.pdf. 